\begin{tabular}{|l|l|l|}
\hline \multicolumn{2}{|c|}{ PublisherInfo } \\
\hline \hline PublisherName & $:$ & BioMed Central \\
\hline \hline PublisherLocation & $:$ & London \\
\hline \hline PublisherImprintName & $:$ & BioMed Central \\
\hline \hline
\end{tabular}

\title{
Double-promoting transcription
}

\begin{tabular}{|l|l|l||}
\hline \multicolumn{2}{|c|}{ ArticleInfo } \\
\hline \hline ArticleID & $:$ & 3678 \\
\hline \hline ArticleDOI & $:$ & $10.1186 /$ gb-spotlight-20000508-02 \\
\hline \hline ArticleCitationID & $:$ & spotlight-20000508-02 \\
\hline \hline ArticleSequenceNumber & $:$ & 115 \\
\hline \hline ArticleCategory & $:$ & Research news \\
\hline \hline ArticleFirstPage & $:$ & 1 \\
\hline \hline ArticleLastPage & $:$ & 2 \\
\hline \hline & & RegistrationDate : 2000-05-08 \\
ArticleHistory & $:$ & OnlineDate $\quad$ 2000-05-08 \\
\hline \hline ArticleCopyright & $:$ & BioMed Central Ltd2000 \\
\hline \hline ArticleGrants & $:$ & \\
\hline \hline ArticleContext & $:$ & 130591111 \\
\hline \hline
\end{tabular}




\section{William Wells}

Email: wells@biotext.com

Eukaryotic transcription gets started with the binding of the TATA-binding protein (TBP) to the promoter. This basic machinery is not invariant, however; 1993 saw the discovery of the TBP-related TRF1, which directs an ill-defined set of tissue- and gene-specific transcription events. In the May 5 Science Holmes and Tjian find that tandem promoters in tudor, a fly gene, allow for regulation by both TBP and TRF1 proteins (Science 2000, 288:867-870). The proteins direct transcription from distinct start sites, with TRF1 requiring a TC-rich box. Preliminary gene array analysis suggests that about $5 \%$ of fly genes may respond to TRF1 induction.

\section{References}

1. A new factor related to TATA-binding protein has highly restricted expression patterns in Drosophila.

2. Transcription properties of a cell type-specific TATA-binding protein, TRF.

3. Science Magazines Homepage, [http://www.sciencemag.org/] 